\title{
Ranciéit a doprovodné minerály z Rychaltic u Frýdku-Místku (Morava, Česká republika)
}

\author{
Ranciéite and accompanying minerals from Rychaltice near Frýdek-Místek \\ (Moravia, Czech Republic)
}

\author{
Dalibor Matýsek ${ }^{1)}$, Jakub JiRÁsek $^{2)^{*}}$, Aneta MinaŘíkováp $^{1)}$ a Petr Skupien ${ }^{1)}$ \\ 1)Katedra geologického inženýrství, Hornicko-geologická fakulta, Vysoká škola báňská - Technická univerzita Ostrava, \\ 17. listopadu 15/2172, 70833 Ostrava-Poruba \\ ${ }^{2)}$ Katedra geologie, Př́rodovědecká fakulta, Univerzita Palackého, 17. listopadu 1192/12, 77146 Olomouc; \\ *e-mail: jakub.jirasek@upol.cz
}

Matýsek D, JiRÁsek J, MinaŘíková A, Skupien P (2021) Ranciéit a doprovodné minerály z Rychaltic u Frýdku-Místku (Morava, Česká republika). Bull Mineral Petrolog 29(1): 41-48 ISSN 2570-7337

\begin{abstract}
Recently described small outcrop of the upper part of the Barnasiówka Formation yielded several manganese oxidic minerals. Outcrop at the bank of the Krnalovice Stream (GPS N 49 $38.623^{\prime}$ E 018 $14.630^{\prime}$ ) consists of Lower Turonian greenish to grey-black laminated claystone alternating with grey chert. The whole sequence is a part of the Baška facies of the Silesian Unit, Outer Western Carpathians. In the middle part of the profile occur concretional aggregates containing manganese minerals. The central pale part of these aggregates is composed of quartz (ca. 90 wt.\%), albite (ca. 9 wt.\%), and muscovite, the darker rim of quartz (ca. 80 wt.\%), goethite (ca. 10 wt.\%), illite, todorokite, plagioclase, K-feldspar, and pyrite. Occasionally, remains of Mn-rich siderite were preserved in the cores. We suppose that they are in fact weathering products of carbonate-rich silicites. Manganese oxides also enter fissures in form of thin black coatings. Powder X-ray diffraction proved the presence of todorokite, ranciéite, pyrolusite, and possible vernadite. Todorokite forms black coatings with submetallic lustre, often associating with ranciéite. Ranciéite is dark pink to pinkish -brown, with a metallic lustre. Back-scattered electron images reveal its extremely thin tabular, sometimes undulated crystals and hexagonally oriented intergrowths. Powder diffraction data are strongly affected by preferred orientation, with dominating basal reflections of 001 plane at $7.4849 \AA$ and plane 002 at $3.7424 \AA$. Its average formula from nine WDS spots $\left(\mathrm{Ca}_{0.14} \mathrm{Mg}_{0.01} \mathrm{Ba}_{0.01} \mathrm{~K}_{0.01}\right)_{\Sigma 0.17}\left(\mathrm{Mn}^{4+}{ }_{0.86} \mathrm{Si}_{0.02} \mathrm{Al}_{0.03} \mathrm{Fe}_{0.01}\right)_{\Sigma 0.92} \mathrm{O}_{2.00} \cdot 0.88 \mathrm{H}_{2} \mathrm{O}$ (based on 2 anions, water calculated from the ratio of cation sum $/ \mathrm{H}_{2} \mathrm{O}$ in the formula according to Post et al. 2008) and $\mathrm{CaO} / \mathrm{MnO}_{2}$ ratio 9 to 12 correspond well to the published data for this phase. Ranciéite is a rather common phyllomanganate from various geological environments, but this locality represents its first unambiguous occurrence in the Czech Republic. It closely resembles the one from Polish flysch Carpathians from Nowa Wieś near Rzesów.
\end{abstract}

Key words: ranciéite, todorokite, pyrolusite, Late Cretaceous, Outer Western Carpathians, Czech Republic

Obdrženo 7. 1. 2021; prijiato 3. 5. 2021

\section{Úvod}

Ranciéit patří $\mathrm{k}$ minerálům, které $\mathrm{v}$ rámci vývoje poznání a rozvoje analytických metod prošly poměrně dynamickými změnami. Jako první ho uvádí Leymerie (1859) pod názvem ranciérit $z$ limonitového dolu ve francouzských Pyrenejích. Název minerálu upravuje na současnou podobu ranciéit podle lokality Rancié Lacroix (1910) s tím, že v analýzách vychází na rozdíl od původního popisu významné množství vápníku. Fleischer a Richmond (1943) uvádí vzorec ranciéitu $\left(\mathrm{CaMn}^{2+}\right) \mathrm{Mn}_{4}^{4+} \mathrm{O}_{9} \cdot 3 \mathrm{H}_{2} \mathrm{O}$ jako nejistý. $\mathrm{S}$ novou analýzou, udávající empirický vzorec $(\mathrm{FeO})_{11}(\mathrm{CaO})_{4.1}(\mathrm{MgO})_{3.35}\left(\mathrm{MnO}_{2}\right)_{81.3} \cdot 82 \mathrm{H}_{2} \mathrm{O}$, respektive zjednodušený ( $\mathrm{Fe}, \mathrm{Ca}, \mathrm{Mg}) \mathrm{O} \cdot 4 \mathrm{MnO}_{2} \cdot 4 \mathrm{H}_{2} \mathrm{O}$, přišla Perseil (1967). Dalším významnějším příspěvkem k poznání tohoto minerálu byla publikace Richmonda et al. (1969), kteří potvrzují jeho strukturní jedinečnost a přicházejí s modifikovaným empirickým vzorcem $\mathrm{Ca}_{0.76} \mathrm{Mn}^{2+}{ }_{0.22} \mathrm{Mn}^{4+}{ }_{4.14}$ $\mathrm{O}_{9.26} \cdot 2.95 \mathrm{H}_{2} \mathrm{O}$, respektive idealizovaným vzorcem ( $\mathrm{Ca}$,
$\mathrm{Mn}) \mathrm{O} \cdot 4 \mathrm{MnO}_{2} \cdot 3 \mathrm{H}_{2} \mathrm{O}$. Bardossy a Brindley (1978) přichází s úpravou počtu vázané vody na empirický vzorec $\left(\mathrm{Ca}_{0.5} \mathrm{Mn}^{2+}{ }_{22} \mathrm{Mg}_{0.04}\right) \mathrm{O} \cdot 4 \mathrm{MnO}_{2} \cdot 3.66 \mathrm{H}_{2} \mathrm{O}$, respektive idealizovaný CaMn ${ }_{4} \mathrm{O}_{9} \cdot 4 \mathrm{H}_{2} \mathrm{O}$. Chukhrov et al. (1979, anglický překlad 1981) přicházejí s úpravou ideálního vzorce ranciéitu na $\mathrm{Ca}_{2} \mathrm{Mn}_{6} \mathrm{O}_{14} \cdot \mathrm{nH}_{2} \mathrm{O}$, protože ho považují za strukturně analogický s chalkofánem. Další autoři, například Barrese et al. (1986), se ovšem z neznalosti této práce vracejí k verzi CaMn ${ }_{4}^{4+} \mathrm{O}_{9} \cdot 4 \mathrm{H}_{2} \mathrm{O}$. Další modifikaci krystalochemického vzorce ranciéitu přináší Kim (1993), který ho uvádí ve formě $\mathrm{Ca}_{2-x} \mathrm{Mn}^{4+}{ }_{9-x} \mathrm{O}_{2} \cdot \mathrm{nH}_{2} \mathrm{O}$, kde x představuje podíl vakantních oktaedrických pozic $(x=0.81$ až 1.28). Významný posun $v$ chápání struktury minerálu přinášejí Ertl et al. (2005). Uvažují, na základě studie Lansona et al. (2000), že ranciéit obsahuje přibližně $10 \%$ celkového $\mathrm{Mn}$ ve formě $\mathrm{Mn}^{3+}$ a zbytek ve čtyřmocné formě, zatímco dvojmocný mangan prakticky chybí - jeho obsahy po rozpočtu na empirický vzorec jsou okolo 0.01 apfu při norma- 
lizaci na dva atomy kyslíku, respektive 0.06 apfu při normalizaci na devět atomů kyslíku. Vrstevnatá struktura má také obsahovat průměrně asi $10 \%$ vakancí ve strukturní pozici $\mathrm{Mn}^{4+}$. Poslední studie struktury ranciéitu, založená na využití synchrotronové práškové difrakce (Post et al. 2008), došla k vzorci obsahujícímu pouze čtyřmocný mangan - $\mathrm{Ca}_{0.19} \mathrm{~K}_{0.01}\left(\mathrm{Mn}^{4+}{ }_{0.91} \square_{0.09}\right) \mathrm{O}_{2} \cdot 0.63 \mathrm{H}_{2} \mathrm{O}$.

Strukturně se ranciéit řadí, spolu $\mathrm{s}$ takanelitem, se kterým vytváří izomorfní řadu (Soo 1993), k oxidům, respektive hydroxidům manganu s vrstevnatou strukturou - tzv. fylomanganátům. Krystalová struktura je tvořena izolovanými vrstvami oktaedrů s obsahem $\mathrm{Mn}^{4+}$ a prípadně také $\mathrm{Mn}^{3+}$ a vakancemi (Ertl et al. 2005; Post et al. 2008). V mezivrstevním prostoru jsou uloženy doplňkové kationty, koordinované jednou vrstvou molekul vody. $\mathrm{U}$ takanelitu je $\mathrm{v}$ mezivrstevním prostoru předpokládána převaha $\mathrm{Mn}^{2+}$, u ranciéitu $\mathrm{Ca}^{2+}$. Strukturně blízkými jsou především minerály skupiny birnessitu a tzv. buseritické fáze (buserit-Ca zřejmě odpovídá nově popsanému lagalyitu - Witzke et al. 2017). Pro identifikaci ranciéitu je rozhodující prášková difrakční analýza a použitelná je i Ramanova spektroskopie. Rozdíly $v$ chemickém složení celé řady oxidů $\mathrm{Mn} \mathrm{s}$ obsahem $\mathrm{Ca}^{2+}$ jsou jen malé, obvykle nedostatečné pro spolehlivé určení. Identifikace pomocí práškové difrakce je založena na pozici bazální difrakční linie 001. Ranciéit ji vykazuje u cca $7.52 \AA$, takanelit u $7.4 \AA$, birnessit u cca $6.95-7.0 \AA$, todorokit u $9.5 \AA$ a lagalyit (buserit) u cca $10 \AA$.

Ačkoliv ranciéit nepatří celosvětově k př́liš vzácným minerálům, na území České republiky byl dosud zjištěn pouze jednou. Konkrétně se jedná o identifikace ve směsi manganových oxidů z Komni na Uherskobrodsku (Jirásek et al. 2018). Tento príspěvek podává detailní mineralogickou charakteristiku nového nálezu z Podbeskydí, který byl bez bližších dat zmíněn Stelmachem et al. (2019).

\section{Lokalizace a stručná historie výzkumů}

Studovaný materiál pochází z nevelkého skalního výchozu v katastru obce Rychaltice, na levém břehu Krnalovického potoka (GPS N 49³8.623، E 018 ${ }^{\circ} 14.630^{\circ}$ ), asi 1.85 km vsv. od obce. Nárazový břeh zde odkryl vrstevní sled laminovaných jílovců, které od báze přecházejí z tmavošedých barev do převládajících šedozelených odstínů. Časté je střídání těchto hornin s polohami střípkovitě se rozpadajících zelenošedých rohovců (obr. 1).

Tato lokalita byla objevena P. Stelmachem a mikropaleontologicky zdokumentována v publikaci Stelmacha et al. (2019). Na základě stratigraficky významných mikrofosilií se podařilo doložit spodnoturonské stárí sedimentů a ztotožnit vrstevní sled se svrchní částí barnasiówského souvrství (Barnasiówka Radiolarian Shale Formation) slezské jednotky flyšových Karpat ve smyslu Bąka et al. (2001) a Bąka (2007). V tomto souvrství jsou z polské části Karpat známy projevy mineralizace oxidy Fe-Mn, bohužel bez bližší mineralogické identifikace (Bąk 2007). Autor předpokládá vznik Mn mineralizace alterací Ca-bohatého rodochrozitu, respektive Mn-bohaté karbonátové konkrece. $V$ obdobném stratigrafickém sledu (pestře zbarvené sedimenty s polohami silicitů) byla na našem území na lokalitě Hukvaldy (Skupien et al. 2016) zjištěna př́tomnost $\mathrm{Mn}$ oxidické mineralizace $(0.7$ a $1.0 \mathrm{~nm}$ fáze, pravděpodobný buserit-Ca = lagalyit?, birnessit, zjištěn i todorokit a Cu-analog asbolánu) a oxidů $\mathrm{Fe}$ (hematit a goethit). Podle morfologie částic (drobné pseudomorfózy po romboedrech) je možné předpokládat, že Mn oxidy vznikly alterací Mn-bohatých karbonátů. $\mathrm{Na}$ blízké lokalitě Krnalovice (potok Kašice, príp. Košice) byl $v$ cenomanských sedimentech zjištěn Fe- a Ca-bohatý rodochrozit jako romboedry do $5 \mu \mathrm{m} v$ pórovitém silicitu (Stelmach et al. 2018).

Geologicky jde o oblast flyšových Karpat, náležející bašskému vývoji slezské jednotky. Jedná se o pestrou skupinu mořských sedimentů na úpatí předpokládané elevace (tzv. bašské kordillery) oddělující sedimentační oblasti slezské a podslezské jednotky (Menčík et al. 1983; Eliáš 2000). Geologická situace je komplikovaná silnou tektonizací, typickou pro násunová pásma Vnějších Karpat.

Na lokalitě samotné Stelmach et al. (2019) uvádějí hojné povlaky, jemnozrnné impregnace a kůry konkrecionálních útvarů tvořené manganovými oxidy. Bez publikovaných dat je $v$ textu zmíněna identifikace todorokitu, pyrolusitu a ranciéitu za pomoci práškové rentgenové difrakce.

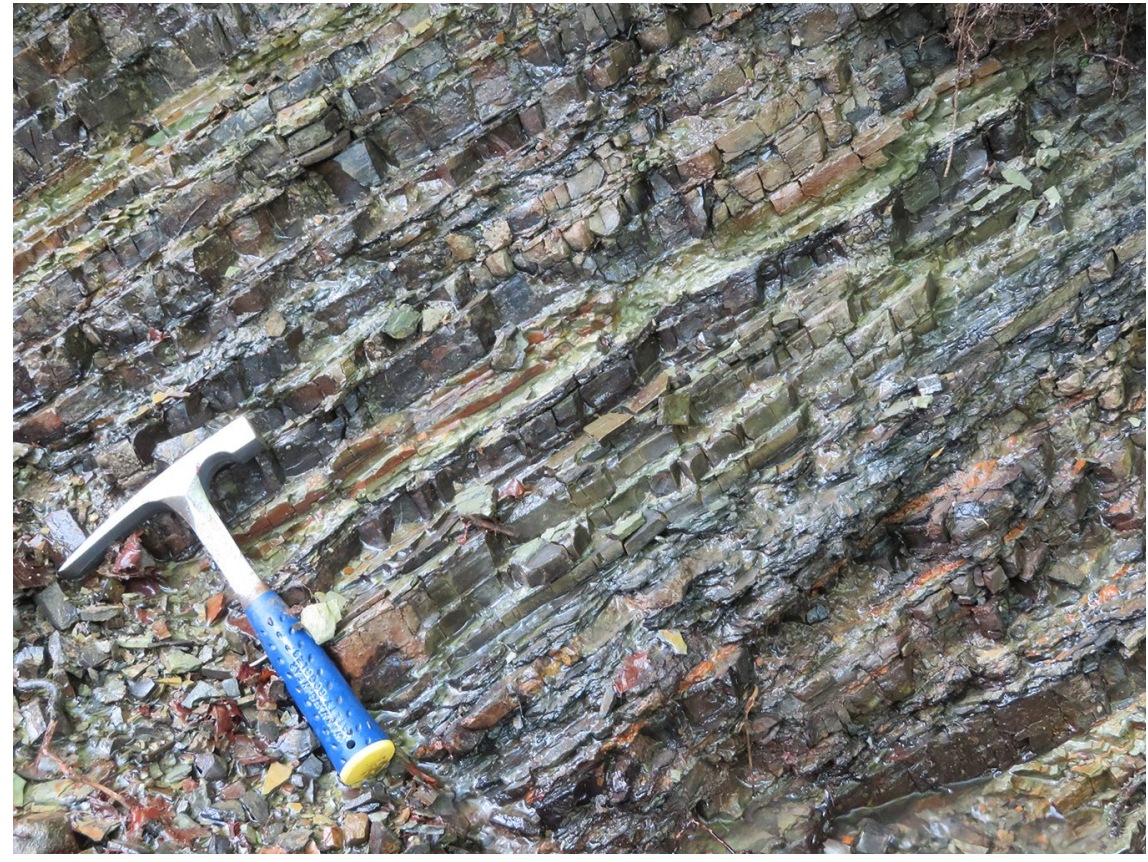

Obr. 1 Stř́dání poloh šedozelených jílovců a zelenavých a šedých rohovců s povlaky minerálů manganu $v$ odkryvu na břehu Krnalovického potoka. Foto J. Jirásek. 


\section{Metodika výzkumu}

Sledování morfologie proběhlo na leštěných nábrusech i př́rodních trhlinách manganem bohatých poloh a konkrecionálních útvarů za použití autoemisního elektronového mikroskopu FEI Quanta-650 FEG od firmy FEI. Mikrofotografie byly pořízeny pomocí detektoru zpětně odražených elektronů (BSE) v režimu chemického gradientu.

Chemické složení ranciéitu bylo studováno kvantitativně pomocí elektronového mikroanalyzátoru Cameca SX 100 (Prírodovědecká fakulta MU, Brno, analytik R. Čopjaková) za podmínek: vinově disperzní analýza, napětí 15 $\mathrm{keV}$, proud $10 \mathrm{nA}$, průměr svazku elektronů do $6 \mu \mathrm{m}$. Jako standardy byly použity dobře definované homogenní minerály a syntetické fáze: albit $(\mathrm{Na} K \alpha)$, olivín $(\mathrm{Mg} K \alpha)$, almandin (Fe Ka), sanidin (Al Ka, Al Ka, K Ka), wollastonit $(\mathrm{Ca} K \alpha)$, vanadinit $(\mathrm{Pb} M \alpha)$, gahnit ( $\mathrm{Zn} K \alpha)$, topaz ( $F K \alpha)$, spessartin $(\mathrm{Mn} \mathrm{K \alpha}), \mathrm{SrSO}_{4}(\mathrm{Sr} L \alpha)$ a baryt $(\mathrm{Ba} L \alpha)$. Empirický krystalochemický vzorec ranciéitu byl přepočten na základ 2 aniontů (kyslík + fluor). Množství vody u něj bylo dopočteno na základě poměru sumy kationtů a $\mathrm{H}_{2} \mathrm{O}$ v ideálním vzorci minerálu podle Posta et al. (2008).
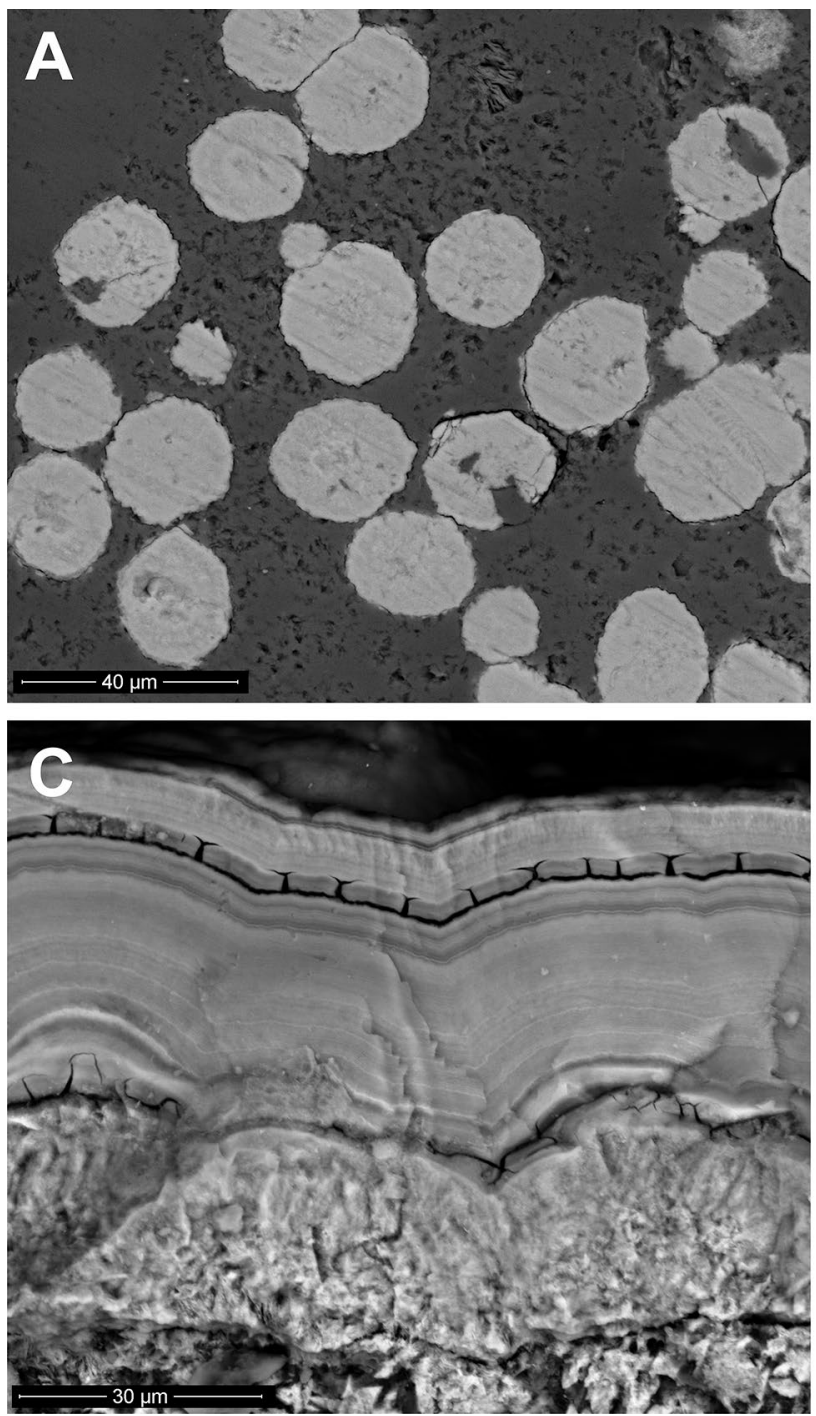

Pomocí práškové rentgenové difrakční analýzy byla sledována struktura přitomných fází. Měření probíhalo na přístroji Bruker-AXS D8 Advance (Katedra geologic-

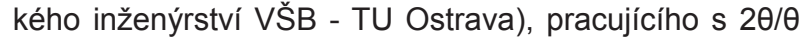
reflexní geometrií měření a s polovodičovým silicon strip detektorem LynxEye za podmínek: záření CuKa/Ni filtr, napětí $40 \mathrm{kV}$, proud $40 \mathrm{~mA}$, krokový režim s krokem $0.014^{\circ} 2 \theta$ a s celkovým časem na kroku $5 \mathrm{~s}$. Mřížkové parametry ranciéitu byly vypočteny Rietveldovou metodou pomocí programu Bruker AXS Topas verze 5.

\section{Výsledky}

Mineralogické studium bylo zaměřeno především na produkty transformace manganových minerálů $\mathrm{v}$ části vzorků ze studované lokality. Pouze orientačně bylo u silicitů ověřeno (pomocí metody "charge contrast imaging" na SEM, např. Watt et al. 2000), že se jedná o bioklastické silicity. Metoda ukazuje, že silicity obsahují hojně silně resorbované a rekrystalované okrouhlé až válcovité útvary, které je možné interpretovat jako bliže neurčitelné jehlice hub, případně i zbytky radiolarií. Prášková RTG difrakční analýza ukázala, že silicity jsou tvořeny mikrokrystalickým

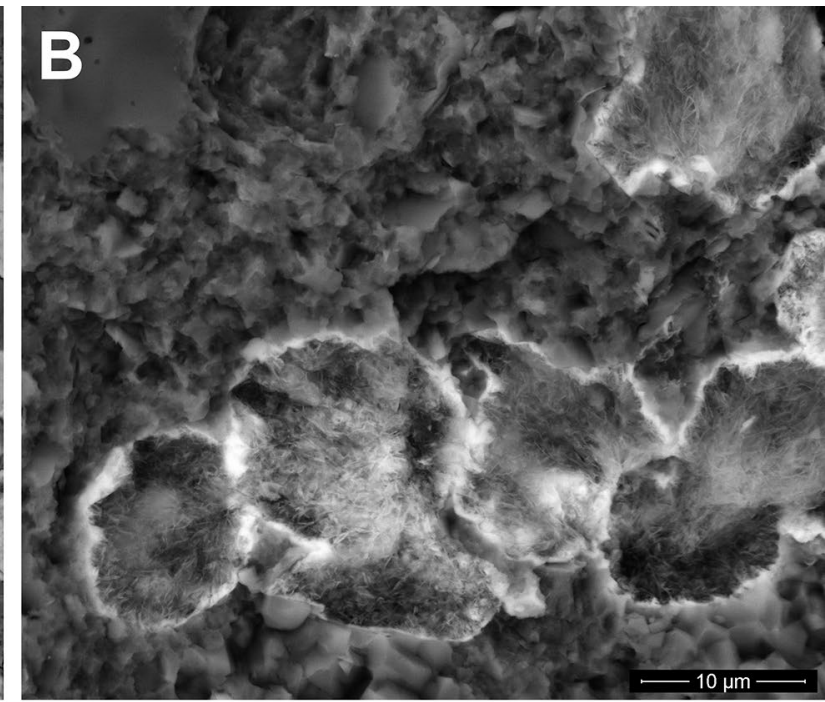

Obr. 2 Charakter manganové mineralizace zobrazený pomocí zpětně odražených elektronů. A - silicit s kulovými dutinami vyplněnými pravděpodobně todorokitem, $B$ - silicit s méně pravidelnými kulovými dutinami zčásti vyplněnými pravděpodobně todorokitem, C - ledvinitý agregát Mn-oxidických minerálů na puklině silicitu s patrnou vrstevnatou stavbou, D - pseudomorfózy romboedrického omezení po Fe-Mn karbonátech tvořené todorokitem a goethitem. Foto D. Matýsek.

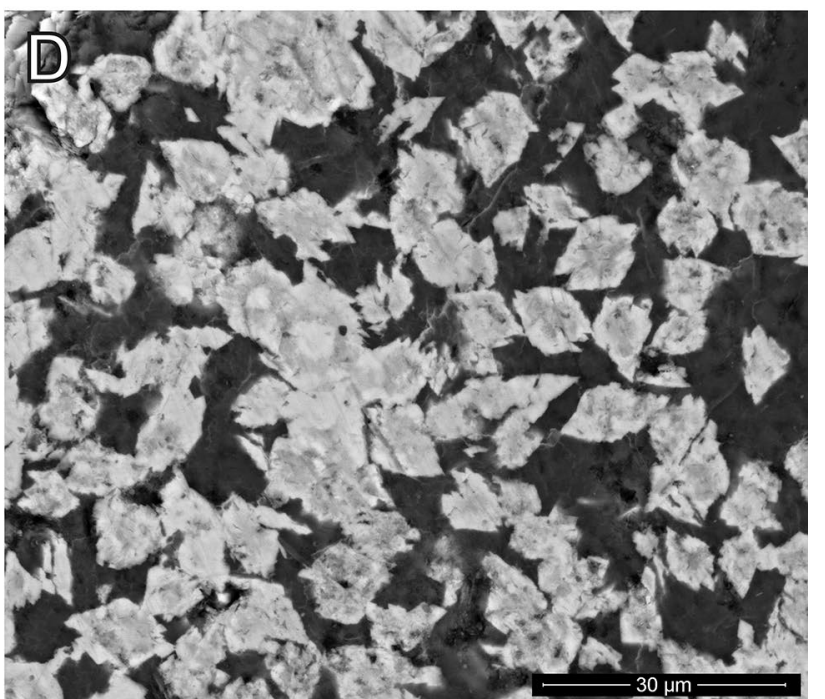




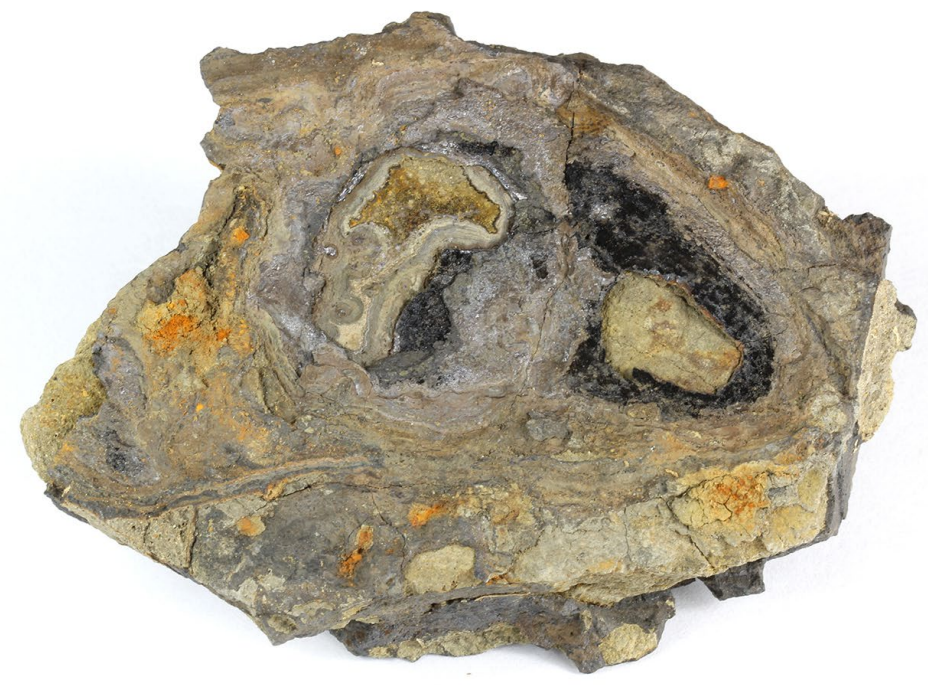

Obr. 3 Konkrecionální útvar s manganovou mineralizací. Černý povlak je tvořen dominantním todorokitem, růžovohnědý ranciéitem. Velikost $8.5 \times 6 \mathrm{~cm}$. Foto A. Minaříková.

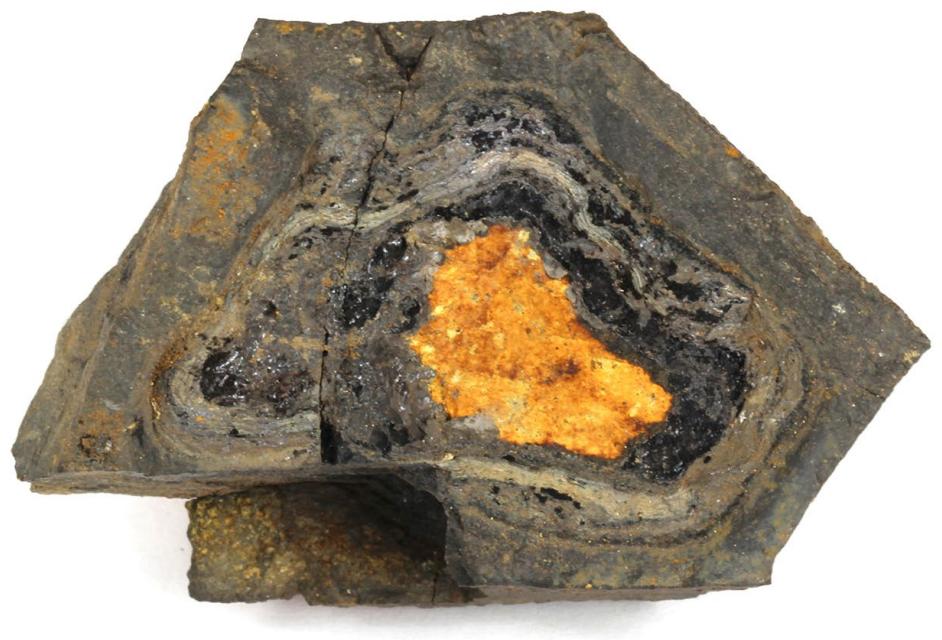

Obr. 4 Konkrecionální útvar s manganovou mineralizací. Černý povlak je tvořen dominantním todorokitem, růžovohnědé pásky ranciéitem. Velikost 4.5×3.5 $\mathrm{cm}$. Foto A. Minaříková.

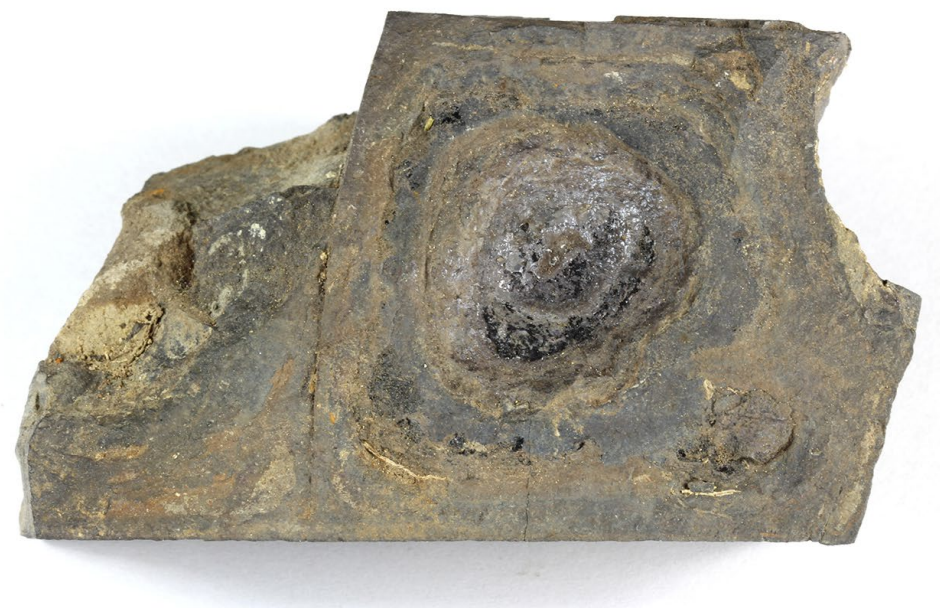

Obr. 5 Konkrecionální útvar s manganovou mineralizací. Růžovohnědý lesklý povlak ve středu útvaru je tvořen ranciéitem. Velikost $6.5 \times 4 \mathrm{~cm}$. Foto $A$. Minařiková. křemenem, bez stop opálové komponenty. Silicity $v$ některých vzorcích obsahují kruhové dutiny nejasné geneze, mající průměr kolem $20 \mu \mathrm{m}$. Ty jsou vyplněné oxidy $\mathrm{Mn}$, velmi pravděpodobně todorokitem (obr. 2A,B), nebo jsou volné a jsou lokalizovány v základní křemité hmotě mimo zbytky mikroorganizmů. Může se snad jednat o dutiny po bakteriích.

Materiál ze středu zkoumaného profilu (vzorky KRN 4 a 5 podle Stelmacha et al. 2019) je silně fragmentován na hranolovité úlomky o velikosti do $5 \mathrm{~cm}$, které makroskopicky vykazují zajímavou koncentrickou až konkrecionální strukturu (obr. 3 - 5). Okraje úlomků jsou do hloubky cca 1 cm tvořeny jemnozrnnou, černou až černohnědou hmotou, centra úlomků jsou světle okrově hnědá, dosti rozpadavá a mají charakter pískovce. Mimo tyto konkrecionální útvary vytvářejí manganové oxidy také povlaky na stěnách puklin a také jemnozrnné impregnace $v$ silicitech. Impregnace oxidy $\mathrm{Mn}$ je patrná téměr̆ $\checkmark$ celé studované sekvenci.

$\mathrm{V}$ relativně homogenních silicitech byla zjištěna impregnace oxidů manganu především podél puklin (obr. 2C). V nábrusech vykazují silicity brekciovitou až skvrnitou strukturu černých Mn oxidů v šedozelené základní hmotě.

Pomocí práškové rentgenové difrakce bylo zjištěno, že tmavý lem konkrecionálních úlomků je tvořen především z křemene (odhad z Rietveldovy analýzy cca $80 \mathrm{hm}$. \%). Dále byl zjištěn goethit (cca $10 \%$ ) a relativně malé množství illitu. Ve stopách (do $2 \%$ ) byl zjištěn todorokit, plagioklas a draselný živec. $V$ lemu byl zjištěn i pyrit a pseudomorfózy po něm. Pomocí SEM bylo zjištěno, že lem je tvořen masivním silicitem $s$ velmi hojnými, nehomogenně rozptýlenými pseudomorfózami romboedrického omezení (obr. 2D), podle rentgenové difrakce tvořenými todorokitem a goethitem.

Okrově zbarvený střed konkrecionálních úlomků obsahuje křemen (cca $90 \mathrm{hm}$. \%), albit (cca $9 \mathrm{hm}$. \%) a stopy muskovitu. Má charakter silně korodovaného, pórovitého silicitu, občas s písčitými zrny a zbytky křemitých organizmů. Vzácně byly $v$ centrální části zjištěny i zbytky Mn -bohatého sideritu. Je pravděpodobné, že centrální části reprezentují silicit s vysokým podílem karbonátů, které byly následně vylouženy. Je pro to potřeba předpokládat mírnou acidifikaci $v$ redukčním prostředí. 
V celé studované sekvenci byla hojně zjištěna puklinová mineralizace oxidů, respektive oxihydroxidů či hydratovaných oxidů Mn. Oxidační produkty $\mathrm{Fe} v$ puklinách jsou na lokalitě dosti vzácné, zjištěn byl jen práškovitý goethit. Manganové minerály $v$ puklinách nejsou ani makroskopicky jednotného vzhledu a složení. Jedná se o tenké povlaky černého a narǔžověle šedého vzhledu s matným až silně kovovým leskem. Část puklinových výplní vykazuje hustě koncentrickou zonální stavbu, kdy se střídají zóny s odlišným leskem a barvou. Velmi pravděpodobně se jedná o tzv. Liesegangovy kruhy či pruhy, které bývají interpretovány jako projev difuze a následné precipitace v difuzně hustém prostředí (Cartwright et al. 1999; Krug, Brandstädter 1999).

$\checkmark$ puklinách byly pomocí práškové rentgenové difrakce identifikovány todorokit, pyroluzit a ranciéit. Sporná je identifikace vernaditu, prípadně jemu podobného RTG téměř amorfního oxidu Mn. Pyroluzit byl nalezen jen na jednom vzorku v podobě povlaku drobných krystalů (obr.
6A). Jeho mřižžkové parametry jsou uvedeny v tabulce 1.

Todorokit je zřejmě nejhojnějším Mn oxidem na lokalitě, bývá ale jemně rozptýlený a vytváří černé, mírně lesklé povlaky (obr. $3-5,6 \mathrm{~B}$ ), dost často ve směsi s ranciéitem. Amorfní Mn oxidy (snad vernadit) vytvářejí matně černé tenké výplně puklin, obvykle ve směsi s todorokitem.

Ranciéit vykazuje tmavě růžovou až růžově hnědou barvu a velmi silný slídový lesk (obr. 3 - 5). Na lokalitě je dosti hojný a je ze zjištěných minerálů zřejmě nejzajímavější. Elektronová mikroskopie ranciéitových výplní puklin ukazuje, že minerál vytváří povlaky, složené z extrémně tenkých, submikrometrových tabulkovitých krystalů. Patrné je i zvlnění lupenů a hexagonálně orientované srůsty tabulek (obr. 6C-F). Difrakční data ukazují na významné, při použité metodice neřešitelné ovlivnění záznamů přednostní orientací podle štěpnosti. $V$ difrakčním záznamu zcela dominují bazální difrakční linie, především 001 $7.4849 \AA$ a 002 - $3.7424 \AA$. Hodnota d 001 kolem 7.5 $\AA$ je pro ranciéit charakteristická, Ertl et al. (2005) uvádí

Tabulka 1 Mřižková data zjištěných minerálů a jejich srovnání s publikovanými údaji.

\begin{tabular}{llllcc}
\hline \multirow{2}{*}{ minerál } & \multirow{2}{*}{ zdroj dat } & prostorová grupa & \multicolumn{2}{c}{ mř́žkové parametry } & \multicolumn{2}{c}{ objem základní buňky } \\
& & & $a(\AA)$ & $c(\AA)$ & 46.97 \\
\hline \multirow{2}{*}{ ranciéit } & tato studie & $P-3$ & $2.658(4)$ & $7.67(1)$ & 52.99 \\
& Post et al. (2008) & $P-3$ & $2.8520(2)$ & $7.523(1)$ & 55.83 \\
\multirow{2}{*}{ pyrolusit } & tato studie & $P 4_{2} / \mathrm{mnm}$ & $4.4103(2)$ & $2.8704(3)$ & 55.89 \\
& RRUFF (2020) & $P 4_{2} / \mathrm{mnm}$ & $4.4123(5)$ & $2.8710(8)$ & \\
\hline
\end{tabular}

Tabulka 2 Chemické složení ranciéitu (hmot. \%) a přepočet koeficientů jejich empirických vzorců na dva atomy kyslíku. Množství vody bylo dopočteno na základě poměru sumy kationtů / $\mathrm{H}_{2} \mathrm{O}$ v ideálním vzorci (0.63 pfu). B.d.I. - pod detekčním limitem.

\begin{tabular}{|c|c|c|c|c|c|c|c|c|c|c|}
\hline & mean & 1 & 2 & 3 & 4 & 5 & 6 & 7 & 8 & 9 \\
\hline $\mathrm{Na}_{2} \mathrm{O}$ & 0.09 & 0.02 & 0.06 & 0.16 & 0.02 & 0.20 & 0.10 & 0.10 & 0.01 & 0.02 \\
\hline $\mathrm{K}_{2} \mathrm{O}$ & 0.26 & 0.20 & 0.24 & 0.16 & 0.22 & 0.19 & 0.38 & 0.30 & 0.25 & 0.46 \\
\hline $\mathrm{MgO}$ & 0.31 & 0.21 & 0.22 & 0.22 & 0.23 & 0.27 & 0.37 & 0.43 & 0.38 & 0.47 \\
\hline $\mathrm{CaO}$ & 7.90 & 8.76 & 8.41 & 7.39 & 8.86 & 8.58 & 7.37 & 6.79 & 6.97 & 7.97 \\
\hline $\mathrm{SrO}$ & 0.05 & b.d.l. & b.d.l. & b.d.l. & b.d.l. & b.d.l. & 0.12 & 0.12 & 0.23 & b.d.l. \\
\hline $\mathrm{BaO}$ & 1.11 & 0.75 & 0.92 & 0.84 & 0.92 & 1.01 & 0.91 & 1.75 & 2.43 & 0.46 \\
\hline $\mathrm{Fe}_{2} \mathrm{O}_{3}$ & 1.24 & 0.60 & 0.73 & 0.80 & 0.78 & 0.79 & 2.17 & 1.90 & 2.03 & 1.38 \\
\hline $\mathrm{Al}_{2} \mathrm{O}_{3}$ & 1.67 & 0.75 & 3.23 & 0.82 & 1.01 & 0.50 & 2.85 & 1.56 & 1.66 & 2.69 \\
\hline $\mathrm{MnO}_{2}$ & 75.78 & 73.98 & 69.76 & 66.10 & 79.69 & 75.97 & 78.79 & 76.64 & 80.65 & 80.46 \\
\hline $\mathrm{SiO}_{2}^{2}$ & 1.62 & 0.27 & 0.33 & 0.36 & 0.29 & 0.25 & 4.80 & 3.98 & 1.55 & 2.73 \\
\hline $\mathrm{F}^{2}$ & 0.03 & b.d.l. & 0.12 & 0.20 & b.d.l. & b.d.l. & b.d.l. & b.d.l. & b.d.l. & b.d.l. \\
\hline $\mathrm{H}_{2} \mathrm{O}^{*}$ & 12.30 & 11.75 & 11.45 & 10.52 & 12.58 & 12.03 & 13.41 & 12.76 & 12.91 & 13.28 \\
\hline$\Sigma$ & 102.38 & 97.30 & 95.46 & 87.55 & 104.59 & 99.78 & 111.26 & 106.31 & 109.08 & 110.05 \\
\hline $\mathrm{Na}^{+}$ & 0.003 & 0.001 & 0.002 & 0.006 & 0.001 & 0.007 & 0.003 & 0.003 & 0.000 & 0.005 \\
\hline $\mathrm{K}^{+}$ & 0.005 & 0.004 & 0.005 & 0.004 & 0.005 & 0.004 & 0.007 & 0.006 & 0.005 & 0.009 \\
\hline $\mathrm{Mg}^{2+}$ & 0.007 & 0.005 & 0.006 & 0.006 & 0.006 & 0.007 & 0.008 & 0.010 & 0.009 & 0.010 \\
\hline $\mathrm{Ca}^{2+}$ & 0.140 & 0.163 & 0.158 & 0.153 & 0.153 & 0.156 & 0.117 & 0.114 & 0.116 & 0.129 \\
\hline $\mathrm{Sr}^{2+}$ & 0.000 & 0.000 & 0.000 & 0.000 & 0.000 & 0.000 & 0.001 & 0.001 & 0.002 & 0.000 \\
\hline $\mathrm{Ba}^{2+}$ & 0.007 & 0.005 & 0.006 & 0.006 & 0.006 & 0.007 & 0.005 & 0.011 & 0.015 & 0.003 \\
\hline$\Sigma$ & 0.163 & 0.179 & 0.178 & 0.175 & 0.170 & 0.181 & 0.141 & 0.144 & 0.147 & 0.155 \\
\hline $\mathrm{Fe}^{3+}$ & 0.015 & 0.008 & 0.010 & 0.012 & 0.009 & 0.010 & 0.024 & 0.022 & 0.024 & 0.016 \\
\hline $\mathrm{Al}^{3+}$ & 0.032 & 0.015 & 0.067 & 0.019 & 0.019 & 0.010 & 0.050 & 0.029 & 0.030 & 0.048 \\
\hline $\mathrm{Mn}^{4+}$ & 0.860 & 0.890 & 0.848 & 0.882 & 0.890 & 0.893 & 0.806 & 0.829 & 0.864 & 0.837 \\
\hline $\mathrm{Si}^{4+}$ & 0.025 & 0.005 & 0.006 & 0.007 & 0.005 & 0.004 & 0.071 & 0.062 & 0.024 & 0.041 \\
\hline$\Sigma$ & 0.932 & 0.918 & 0.930 & 0.919 & 0.924 & 0.917 & 0.950 & 0.943 & 0.942 & 0.942 \\
\hline $\mathrm{F}^{-}$ & 0.002 & 0.000 & 0.006 & 0.012 & 0.000 & 0.000 & 0.000 & 0.000 & 0.000 & 0.000 \\
\hline $\mathrm{O}^{2-}$ & 2.000 & 2.000 & 2.000 & 2.000 & 2.000 & 2.000 & 2.000 & 2.000 & 2.000 & 2.000 \\
\hline $\mathrm{H}_{2} \mathrm{O}^{*}$ & 0.878 & 0.786 & 0.758 & 0.634 & 0.906 & 0.823 & 1.055 & 0.948 & 0.970 & 1.027 \\
\hline
\end{tabular}


hodnoty v rozmezí mezi 7.48 až 7.57 Å. Rietveldova analýza s použitím vstupních dat podle Ertla et al. (2005) sice poskytuje odhad mřížkových parametrů (tab. 1), výsledky nejsou ale zcela věrohodné a jsou zatížené i poměrně velkou chybou. Diference, tj. rozdíl mezi modelovaným a měřeným záznamem, naznačuje i př́tomnost nepokrytých slabých satelitních linií. Použitý vstupní model je jednak poměrně vágní a obsahuje pravděpodobně ne zcela správné pozice molekul vody $v$ mezivrstevním prostoru. Obdobně vychází i použití vstupních dat podle Posta et
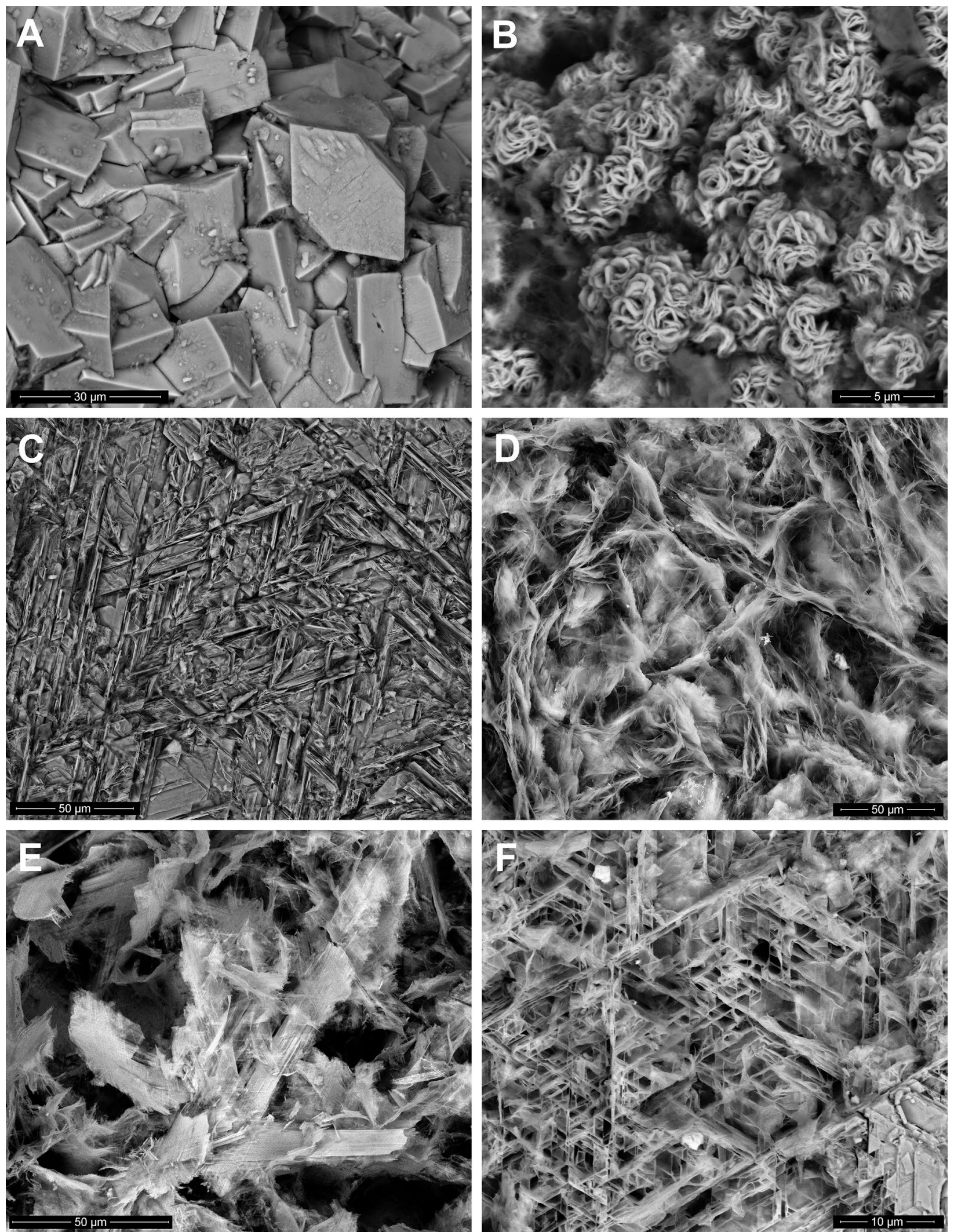

Obr. 6 Charakter manganové mineralizace na puklinách silicitů zobrazený pomocí zpětně odražených elektronů. A agregát krystalů pyrolusitu, $B$ - rozety todorokitu, C-F - povlaky ranciéitu složené z extrémně tenkých tabulkovitých krystalů, místy s patrnou hexagonální symetrií (E, F). Foto D. Matýsek. 
al. (2008). Nevyřešený, ale velmi pravděpodobný, je i vliv případné polytypie, která u ranciéitu dosud nebyla sledována. Odhad velikostí koherentně difraktujících domén je ca $6.4 \mathrm{~nm}$, což ukazuje na významný podíl strukturního porušení a materiál nebude možné použít pro případnou monokrystalovou difrakci.

Výsledky WDS bodové mikroanalýzy ranciéitu jsou uvedeny $\mathrm{v}$ tabulce 2 . Empirický průměrný krystalochemický vzorec $\left(\mathrm{Ca}_{0.14} \mathrm{Mg}_{0.01} \mathrm{Ba}_{0.01} \mathrm{~K}_{0.01}\right)_{\Sigma 0.17}\left(\mathrm{Mn}^{4+}{ }_{0.86} \mathrm{Si}_{0.02} \mathrm{Al}_{0.03}\right.$ $\left.\mathrm{Fe}_{0.01}\right)_{\Sigma 0.92} \mathrm{O}_{2.00} \cdot 0.88 \mathrm{H}_{2} \mathrm{O}$ dobre odpovídá publikovaným údajům. Obsah Na dosáhl maximálně 0.007 apfu, obsah Sr maximálně 0.002 apfu a obsah $\mathrm{F}$ maximálně 0.012 apfu $v$ jednotlivých měřených bodech. Obsahy $\mathrm{Pb}$ a $\mathrm{Zn}$ byly ve všech bodových analýzách pod mezí detekce použité analytické metody. Zjištěné procentuální poměry $\mathrm{CaO} / \mathrm{MnO}_{2}$ se pohybují od 9 do 12; odpovídají publikovaným hodnotám pro ranciéit (Cottrell, Jenkins 2008) a vylučují, že by se mohlo jednat o takanelit, který s ranciéitem tvoří pevný roztok (Kim 1993). Mírně zvýšený obsah $\mathrm{SiO}_{2}$ a $\mathrm{Al}_{2} \mathrm{O}_{3} \vee$ analyzovaných bodech 6 až 9 může svědčit o kontaminaci lupenitých agregátů ranciéitu alumosilikáty.

\section{Závěr}

Ranciéit přestavuje celosvětově poměrně běžný fylomanganát. Nejčastěji se vyskytuje $v$ oxidační zóně manganových nebo železo-manganových ložisek (např. Leymerie 1859; Chukhrov et al. 1979; Nimfopoulos et al. 1997a; Vasileva, Ruskov 2007). Objeven byl ale také $v$ jeskynních sedimentech (Bónová et al. 2009b), připovrchových partiích zvětralých karbonátových hornin (Bardossy, Brindley 1978; Nimfopoulos et al. 1997b; Ertl et al. 2005; Bónová et al. 2009a), jako recentní ve starých důlních dílech (Cottrell, Jenkins 2008), aj.

V České republice byl dosud uváděn jako nejistý ze dvou výskytů. Prvním je výchoz sedimentů veřovického souvrství slezské jednotky v Soběšovicích, kde byly na sideritickém jílovci zjištěny povlaky goethitu, manganitu, pyrolusitu a Mn-oxidu se zvýšeným obsahem Ca, který by mohl odpovídat ranciéitu (Matýsek, Skupien 2015). Naopak výskyt ranciéitu z Komni na alterovaném andezitu ve směsi s todorokitem a birnessitem byl ověřen pouze pomocí práškového rentgenového studia, bez potvrzení jeho chemismu (Jirásek et al. 2018). Lokalita Rychaltice tak představuje nejvěrohodněji zdokumentovaný výskyt tohoto minerálu na našem území a po geologické stránce je velmi podobná výskytu ranciéitu $v$ polských flyšových Karpatech na lokalitě Nowa Wieś u Rzesówa (Franus et al. 2000).

\section{Poděkování}

Vznik tohoto článku byl finančně podpořen grantovými projekty Ministerstva školství, mládeže a tělovýchovy ČR SGS SP2019/77 a SP2020/170 a využil techniku získanou díky projektu L01406 stejného poskytovatele. Zapojená studentka za finanční podporu děkuje dotačnímu programu „Podpora vědy a výzkumu v Moravskoslezském kraji 2019" (RRC/10/2019) financovanému z rozpočtu Moravskoslezského kraje. Za poznámky vedoucí ke zvýšení kvality príspěvku děkujeme oběma recenzentům - P. Paulišovi a Z. Dolníčkovi.

\section{Literatura}

BĄK K (2007) Organic-rich and manganese sedimentation during the Cenomanian-Turonian boundary event in the Outer Carpathian basins; a new record from the Skole Nappe, Poland. Palaeogeogr Palaeocl 256(12): 21-46

BĄK K, BĄK M, PAUL Z (2001) Barnasiówka Radiolarian Shale Formation - a new lithostratigraphic unit in the Upper Cenomanian-Lowermost Turonian of the Polish Outer Carpathians (Silesian Series). Ann Soc Geol Pol 71(2): 75-103

BARDossy G, BRINDLEY GW (1978) Rancieite associated with a karstic bauxite deposits. Am Mineral 63(78): $762-767$

Barrese E, Giampaolo C, Grubessi O, Mottana A (1986) Ranciéite from Mazzano Romano (Latium, Italy). Mineral Mag 50(355): 111-118

BónOvÁ K, BAČík P, Bóna J (2009 a) Hexahydrit a ranciéit $z$ holocénnych travertínov a penovcov vo Vyšných Ružbachoch (Spišská Magura, severné Slovensko). Bull mineral-petrolog Odd Nár Muz Praha 20(1): 94100

BónovÁ K, Bačí P, Derco J (2009 b) Pyroluzit a ranciéit z jaskyne Skaliský potok (Slovenský kras, východné Slovensko). Mineralia Slov 41(4): 511-518

Cartwright JHE, García-Ruiz JM, Villacampa Al (1999) Pattern formation in crystal growth: Liesegang rings. Comput Phys Commun 121-122: 411-413

Cottrell TF, Jenkins DA (2008) Ranciéite from Mynydd Parys, Amlwch, Anglesey, Wales. J Russell Soc 11: $59-63$

ELıÁš M (2000) Bašský vývoj slezské jednotky a jeho možné ekvivalenty. Zpr Geol Výzk v roce 1999 33: 45-47

Ertl A, Pertlik F, Prem M, Post Je, Kim SJ, Brandstetter F, Schuster R (2005) Ranciéite crystals from Friesach, Carinthia, Austria. Eur J Mineral 17: 163-172

FLEISCHER M, RICHMOND WE (1943) The manganese oxide minerals: a preliminary report. Econ Geol 38(4): 269286

Franus W, Manecki A, Wieser T (2000) Rancieite from clinoptilolite-montmorillonite claystones of the Skole Unit (the Polish Flysch Carpathians). Mineral Polon 31(2): 59-73

Chukhrov FV, Gorshkov Al, Svitsov AV, Berezovskaya VV, RUDNITSKAYA YS (1979) The nature of rancieite. Izv AN SSSR Geol 11: 71-81 (in Russian)

Chukhrov FV, Gorshiov Al, Svitsov AV, Berezovskaya VV, RUDNITSKAYA YS (1981) The nature of rancieite. Int Geol Rev 23(1): 115-124

JiRásek J, MatÝsek D, MinaŘíková A (2018) Oxidické minerály manganu $\mathrm{z}$ jihomoravských andezitoidních hornin (Západní Karpaty). Bull Mineral Petrolog 26(2): 168175

KIM SJ (1993) Chemical and structural variations in rancieite-takanelite solid solution series. $\mathrm{N} \mathrm{Jb}$ Miner Mh 5: 233-240

KRUg H-J, Brandstädter H (1999) Morphological characteristics of Liesegang rings and their simulations. J Phys Chem A 103(39): 7811-7820

LACROIX A (1910) Minéralogie de la France et de ses colonies: Tome quartième. 1-923, Librairie polytechnique, Paris 
Lanson B, Drits VA, Silvester E, Manceau A (2000) Structure of $\mathrm{H}$-exchanged hexagonal birnessite and its mechanism of formation from Na-rich monoclinic buserite at low pH. Am Mineral 85(5-6): 826-838

LeYMeRIE A (1859) Cours de minéralogie (histoire naturelle): Deuxième partie. 1-429, Victor Masson, Paris

MATÝSEK D, SKUPIEN P (2015) The origin of native selenium microparticles during the oxidation of sideritic mudstones in the Veřovice Formation (Outer Western Carpathians). Geol Carpath 66(4): 303-310

Menčík E, Adamová M, Dvořák J, Dudek A, Jetel J, Jurková A, Hanzlíková E, Houša V, Peslová H, RybáŘová L, Šmíd B, Šebesta J, TYRÁ̌̌EK J, VAŠlČEK Z (1983) Geologie Moravskoslezských Beskyd a Podbeskydské pahorkatiny. 1-307, Academia, Praha

Nimfopoulos MK, Michalidis KM, Christofides G (1997a) Zincian rancieite from the Kato Nevrokopi manganese deposit, Macedonia, northern Greece. In Nicholson K, Hein JR, Bühn B, Dasgupta S (eds.) Manganese mineralization: geochemistry and mineralogy of terrestrial and marine deposits. 339-347. Geological Society special publication 119, The Geological Society London

Nimfopoulos MK, Pattrick RAD, Michalidis KM, Polya DA, Esson J (1997b) Geology, geochemistry, and origin of the continental karst-hosted supergene manganese deposits in the Western Rhodope Massif, Macedonia, Northern Greece. Explor Min Geol 6(2): 171-184

Perseil E-A (1967) Nouvelles données sur la Ranciéite du Rancié. Comptes rendus hebdomadaires des séances de l'Académie des sciences, Série D: Sciences naturelles, 264: 1241-1244
Post JE, Heaney PJ, Ertl A (2008) Rietveld refinement of the ranciéite structure using synchrotron powder diffraction data. Powder Diffr 23(1): 10-14

Richmond WE, Fleischer M, Mrose ME (1969) Studies on manganese oxide minerals. IX. Rancieite. B Soc Fr Mineral Cr 92: 191-195

RRUFF DATABASE (2020) Př́stup 29. řijna 2020 na adrese https://rruff.info/Pyrolusite/R050361

Skupien P, Matýsek D, Boorová D, Pavluš J, Doupovcová $P$ (2016) Pestré vrstvy svrchní křídy v bašském vývoji slezské jednotky. Zpr Geol Výzk 49(1): 203-208

Stelmach P, Skupien P, MatÝsek D (2018) Biostratigrafie a litologie slínovců a silicitů cenomanského stáří na bázi bašského souvrství potoka Kašice. Zpr Geol Výzk 51(2): 149-155

Stelmach P, Skupien P, Matýsek D (2019) Biostratigrafie, litologie a mineralogie hlubokovodních sedimentů barnasiówského souvrství na břehu Krnalovického potoka u Rychaltic. Zpr Geol Výzk 52(2): 135-140

VASILEVA M, Ruskov K (2007) Ca-phyllomanganate (rancieite) from the Kremikovtsi iron deposit. Annual of the University of Mining and Geology "St. Ivan Rilski" 50(1): 29-36 (in Bulgarian)

WATt GR, GRIFFIN BJ, KInNY PD (2000) Charge contrast imaging of geological materials in the environmental scanning electron microscope. Am Mineral 85(11-12): 1784-1794

Witzke T, Pöllman H, Gardolinski JefC, Sommariva M (2017) Lagalyite. IMA No. 2016-106. Mineral Mag 81(2): 406 